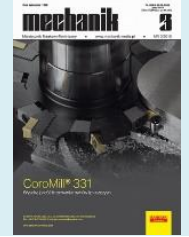

Authors: Andrzej Nowakowski, Tadeusz Krzywda, Piotr Putyra

Title of article: „Obróbka EDM ceramiki spiekanej metodą SPS” („EDM processing of sintered ceramic materials using the SPS method")

Mechanik, Vol. 91, No. 3 (2018): pages 240-243

DOI: https://doi.org/10.17814/mechanik.2018.3.39

\title{
EDM processing of sintered ceramic materials using the SPS method
}

\author{
Obróbka EDM ceramiki spiekanej metodą SPS
}

\section{ANDRZEJ NOWAKOWSKI TADEUSZ KRZYWDA PIOTR PUTYRA *}

Presented are the analysis of physical and mechanical properties of the $\mathrm{Al}_{2} \mathrm{O}_{3}, \mathrm{SiC}$ and $\mathrm{Si}_{3} \mathrm{~N}_{4}$ matrix ceramics with additives of good electrical conductivity phases and $\mathrm{TiB}_{2}$ matrix ceramics. The density, Young's modulus, hardness HV1 and electrical conductivity of each material were investigated. Ceramic composite materials with the participation of the conductive phases have been produced using SPS (spark plasma sintering) method. Materials characterized by good electrical conductivity were shaped using EDM (electro discharge machining) method.

KEYWORDS: ceramic materials, SPS sintering, electro erosion machining

Ceramic materials belong to structures with ionic or covalent bonds. The electrical properties of polycrystalline and multiphase ceramics can be optimized by modifying their surface, composition and intergranular boundaries [1]. In order to be able to shape technical ceramics (oxide or nitride) in the electric discharge machining process, it was necessary to undertake studies to increase its electrical conductivity.

Ceramic materials based on $\mathrm{Al}_{2} \mathrm{O}_{3}$ and $\mathrm{Si}_{3} \mathrm{~N}_{4}$ have many beneficial mechanical properties (high hardness and strength in a wide range of temperatures, resistance to oxidizing and corrosive environments, also at high temperature, resistance to thermal shocks) and are widely used in various areas of life. Ceramic parts with more complicated shapes can be formed in the electric spark erosion process, as long as the material to be machined is of sufficient electrical conductivity. Introduction of natural conductors into the matrix: TiN, TiC, $\mathrm{Ti}(\mathrm{C}, \mathrm{N})$ or $\mathrm{TiB}_{2}$, improves the conductivity of multiphase ceramics and enables the use of electro discharge machining (EDM) for the production of elements with very complex shapes [2-6]. An additional advantage of EDM treatment is the limitation of internal stresses in the object.

In order to obtain the appropriate conductivity of the oxygen ceramic based on $\mathrm{Al}_{2} \mathrm{O}_{3}$ or $\mathrm{ZrO}_{2}$ and be able to use EDM treatment, a ceramic conductive phase (carbide, nitride or boride) should be introduced in an amount of approx. $30 \%$ [7-9]. Materials with resistance of up to $100 \Omega \mathrm{cm}[10,11]$ can be machined using EDM.

\footnotetext{
* Drinż. Andrzej Nowakowski (anowak@ios.krakow.pl), inż. Tadeusz Krzywda (tadeusz.krzywda@ios.krakow.pl), dr inż. Piotr Putyra (piotr.putyra@ios.krakow.pl) - Instytut Zaawansowanych Technologii Wytwarzania
}

\section{Research methodology}

Ceramic composites with a matrix of $\mathrm{Al}_{2} \mathrm{O}_{3}$ and $\mathrm{Si}_{3} \mathrm{~N}_{4}$ were obtained with the addition of phases with good electrical conductivity in the form of $\mathrm{TiB}_{2}, \mathrm{TiC}$ and TiN. The volume fraction of conductive phases in these composites was $30 \div 60 \%$. Oxide phases $\left(\mathrm{Al}_{2} \mathrm{O}_{3}, \mathrm{MgO}\right.$ and $\left.\mathrm{ZrO}_{2}\right)$ were added to composites with a silicon nitride matrix to improve their sinterability.

The individual mixtures were prepared in a high-energy planet mill Pulverisette 6 , the grain size of the batch powders did not exceed $3 \mu \mathrm{m}$. Silicon nitride bowls and balls were used in the process of homogenization of mixtures. After this process, the mixtures were dried and then granulated. Materials were sintered by SPS (Spark Plasma Sintering) method, FCT-HP D 125 device was used for this.

In the SPS sintering process, uniaxial and pulse currents were applied. The direct flow of current through the sintered material allows for high speeds of both heating and cooling. The SPS sintering mechanism is explained by the discharges generated in the spaces between the powder particles, causing local temperature rise, melting of the powder surface and shaping the necks. After forming the neck, resistance heating occurs as a result of current flow through the conductor with a small cross-section (fig. 1). The spark discharge removes adsorbed gases and oxides from the surface of the particles, thereby facilitating the formation of active contacts between the particles of the powder, which leads to a lower temperature and shorter sintering time.

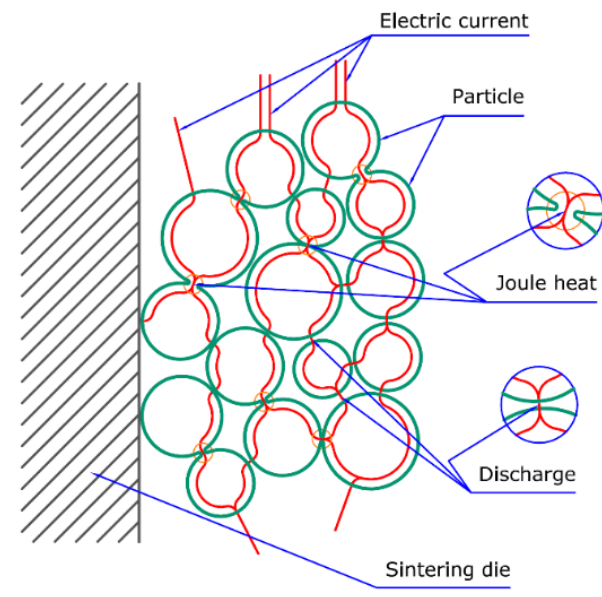

Fig. 1. Current flow diagram during SPS sintering 
Sintering of powders using the SPS method is carried out in graphite matrices, whereby the maximum compression pressure is determined by the strength of the graphite elements to be compressed.

The scheme of the SPS device is shown in fig. 2. The pressing takes place under vacuum conditions, which allows for degassing of powdered powders. Next, protective gas (nitrogen or argon) is introduced into the chamber of the SPS device. The temperature is measured with a pyrometer located in the axis of the ironing punch. The measurement is carried out from the bottom of the graphite punch hole (located approximately $2 \div 3 \mathrm{~mm}$ from the surface of the sintered material), which significantly limits the difference between the temperature of the sample and the temperature of the measuring site.

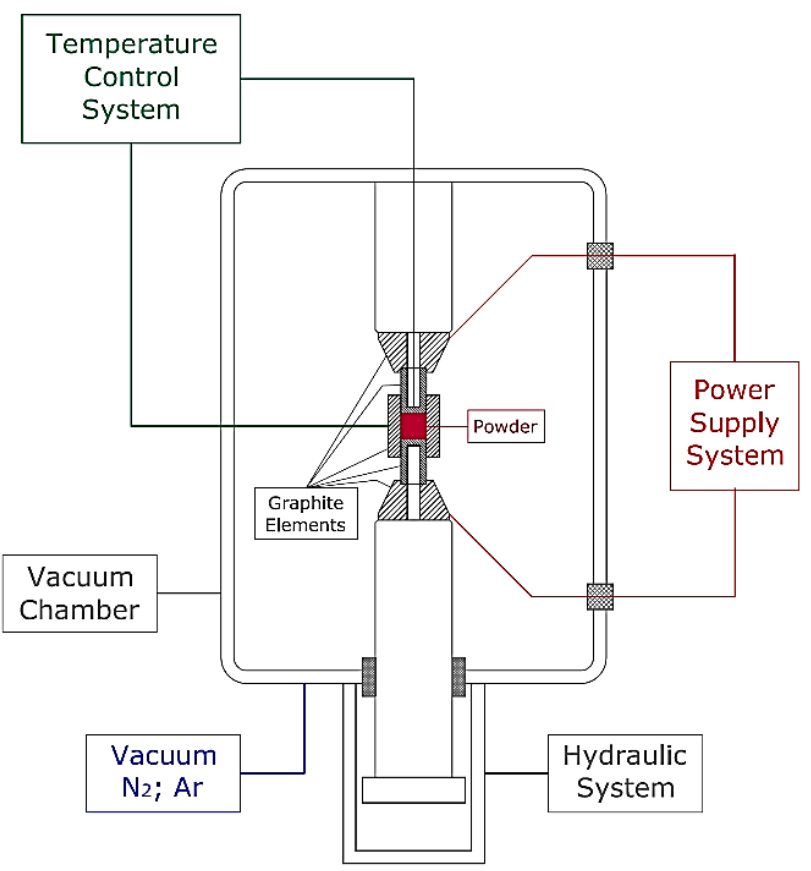

Fig. 2. Scheme of the SPS device

The pressing of powder mixtures took place in a graphite matrix, at a maximum pressure of $35 \mathrm{MPa}$, under vacuum conditions. A protective gas was then introduced into the chamber of the SPS device. The sintering parameters are presented in the table I.

Physical and mechanical tests were carried out on samples whose surfaces were prepared using Struers devices. The apparent density $\rho_{\mathrm{p}}$ was measured by the hydrostatic method (saturation in a vacuum). The $9.81 \mathrm{~N}$ hardness was determined using the Vickers method, using the Future Tech digital micro-hardness meter FM-7. Corp. The Young's modulus was also measured using the ultrasonic method for measuring the transverse and longitudinal wave travel velocities using the Panametrics
Epoch III flaw detector. To measure the resistances presented in the tab. I. Thomson bridge TMT-5 was used. Fig. 3 shows the resistance characteristic of $\mathrm{Si}_{3} \mathrm{~N}_{4}-\mathrm{TiB}_{2}$ measured in the voltage range $0 \div 400 \mathrm{~V}$.

Physical and mechanical properties of materials after sintering are summarized in Table I. Samples after sintering, which were then electro-erosion treated, are shown in fig. 4.

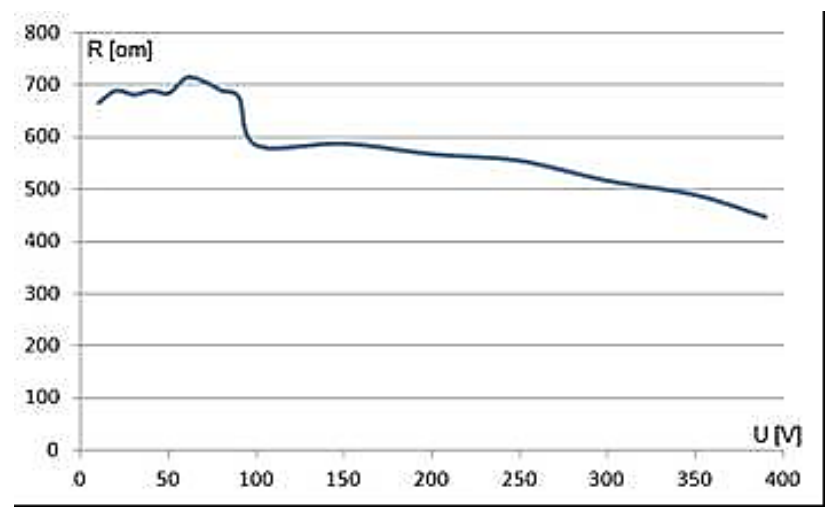

Fig. 3. Dependence of resistance $R$ of a weakly conductive $\mathrm{Si}_{3} \mathrm{~N}_{4}$ composite - $\mathrm{TiB}_{2}$ on $U$ voltage

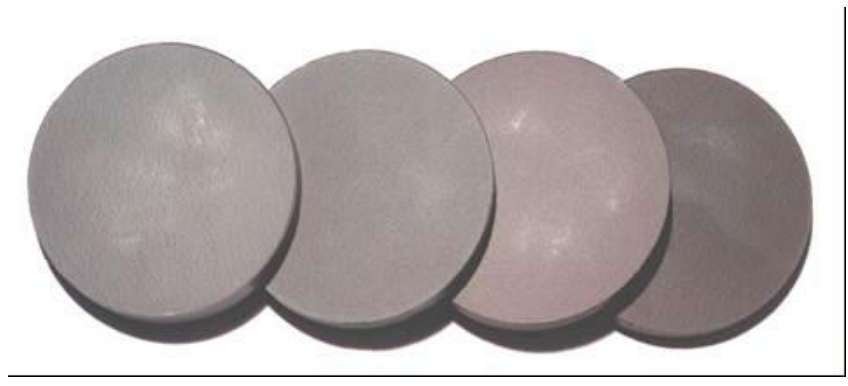

Fig. 4. Samples of ceramic materials for EDM treatment after sintering with the SPS method

\section{Electric discharge treatment of materials}

The EDM shaping process was carried out on an EDEF40 EDM with a UZSDf-40 generator (fig. 5) operating in the iso-energy mode. The EDM machine tool and generator were designed and made at the Institute of Advanced Manufacturing Technologies. The use of the experimental machine made it possible to carry out tests with different variants of the generator's work, namely:

- voltage polarizing the ignition circuit in the range $160 \div 400 \mathrm{~V}$,

- bipolar pulses of the working voltage,

- with the addition of an additional current pulse of high amplitude and short time on the basic pulse of the working current. 
TABLE I. Selected properties of composite materials with a matrix of $\mathrm{SiC}, \mathrm{Si}_{3} \mathrm{~N}_{4}$ and $\mathrm{TiB}_{2}$

\begin{tabular}{|c|c|c|c|c|c|c|}
\hline \multirow{3}{*}{ Material } & \multicolumn{2}{|c|}{ Sintering } & \multirow{2}{*}{$\begin{array}{l}\text { Apparent } \\
\text { density }\end{array}$} & \multirow{2}{*}{ Young's modulus } & \multirow{2}{*}{$\begin{array}{l}\text { Hardness } \\
\text { HV1 }\end{array}$} & \multirow{2}{*}{ Resistance } \\
\hline & temperature & time & & & & \\
\hline & ${ }^{\circ} \mathrm{C}$ & $\min$ & $\mathrm{g} / \mathrm{cm}^{3}$ & $\mathrm{GPa}$ & & $\Omega$ \\
\hline $\begin{array}{l}\mathrm{Al}_{2} \mathrm{O}_{3}+30 \% \mathrm{Ti}(\mathrm{C}, \mathrm{N})+ \\
30 \% \mathrm{TiB}_{2}\end{array}$ & \multirow{3}{*}{1650} & \multirow{3}{*}{1} & 4,22 & 400 & 1850 & 1,1 \\
\hline $\begin{array}{l}\mathrm{Al}_{2} \mathrm{O}_{3}+30 \%(\mathrm{TiC}+\mathrm{TiN}) \\
+10 \% \mathrm{TiB}_{2}\end{array}$ & & & 4,26 & 412 & 1790 & 0,9 \\
\hline $\begin{array}{l}\mathrm{Al}_{2} \mathrm{O}_{3}+30 \%(\mathrm{TiC}+\mathrm{TiN}) \\
+30 \% \mathrm{TiB}_{2}\end{array}$ & & & 4,24 & 410 & 1860 & 0,7 \\
\hline $\mathrm{Si}_{3} \mathrm{~N}_{4}+30 \% \mathrm{TiB}_{2}$ & 1550 & 10 & 3,51 & 318 & 1640 & 1800 \\
\hline
\end{tabular}

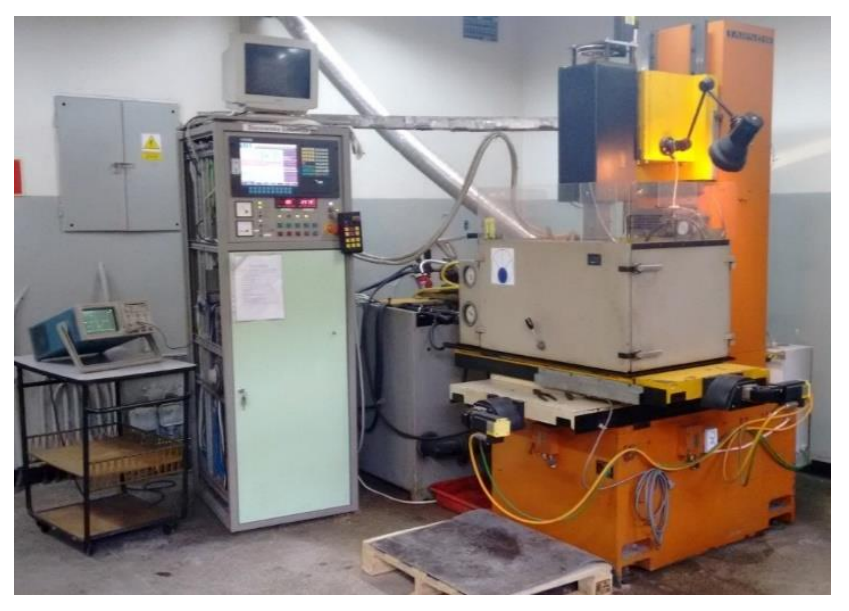

Fig. 5. Experimental EDEF-40 EDM machine

Conducting the research in such conditions would not be possible on a standard electro erosion machine.

The following variants of the electric discharge machining process were tested in the preliminary tests of the electric discharge of the $\mathrm{Al}_{2} \mathrm{O}_{3}-\mathrm{Ti}(\mathrm{C}, \mathrm{N})-\mathrm{TiB}_{2}$ composite:

- positive and negative polarity of electrodes,

- change of current pulse on-time and off- time settings,

- machining with an additional current pulse,

- machining with bipolar pulses,

- changes of the set voltage value to the feed controller,

- changes the ignition voltage in the range of $160 \div 350 \mathrm{~V}$,

- changes in dielectric pressure for flushing the gap.

During the evaluation of the EDM process, the occurrence of arcing and the stability of the regulator of the interelectrode gap thickness were taken into account first of all. The machining was carried out with a copper roller electrode with a diameter of $12 \mathrm{~mm}$. The inter-electrode gap was rinsed with a dielectric liquid pumped through a central hole in the working electrode. The process was carried out in cosmetic kerosene.

During the positive polarity drilling, the controller worked very unstable and arcing was often present, and traces of burns were visible on the treated surface (two internal traces - fig. 6). Attempts to stabilize the process by changing the pulse duty factor, dielectric pressure, ignition voltage and the regulator voltage settings have not produced any effects. After the introduction of the negative polarity and duty factor or pulses of 0.5 or less arcing were eliminated. Therefore, it was assumed that in the EDM treatment of these materials the maximum value of the duty factor will be 0.5 . Typically, a low duty factor is disadvantageous, due to the loss of EDM process efficiency and increased wear of the working electrode.

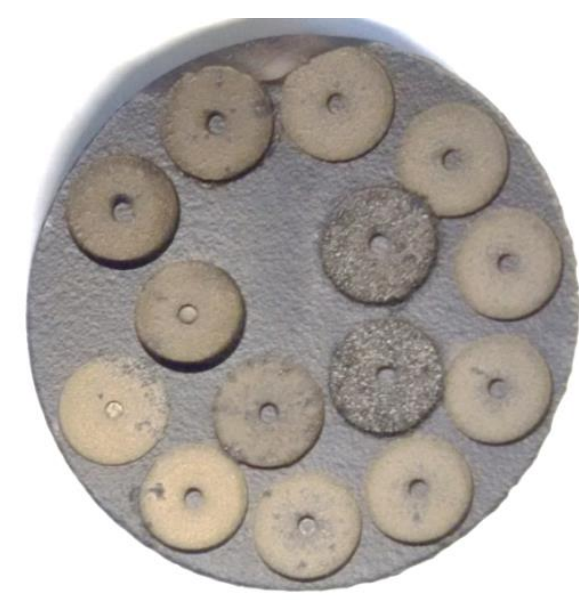

Fig. 6. $\mathrm{Al}_{2} \mathrm{O}_{3}-\mathrm{Ti}(\mathrm{C}, \mathrm{N})-\mathrm{TiB}_{2}$ composite with molds

In further tests, mainly due to avoid arcing, the set voltage of the regulator was set to $50 \mathrm{~V}$. The most favorable for the process stability was the pressure in the rinsing system of $0.7 \mathrm{hPa}$. There was no influence of bipolar pulses on the EDM process. Additional working current pulses were discontinued, because their activation caused immediate arcing. Studies have shown that changes in the ignition voltage in the range of $160 \div 350 \mathrm{~V}$ have not affected the occurrence of arcing, but improved the stability of machining. In order to eliminate arc discharges, along with the increase of the working current, it was necessary to shorten the pulse on-time setting while maintaining the pulse duty factor at 0.5 . It was noted that when the working current exceeded $7 \mathrm{~A}$, the process was destabilized.

On the basis of the preliminary results, a research plan was adopted in which the fixed parameters were:

- M1E copper electrode with a central hole with a diameter of $\varnothing 2 \mathrm{~mm}$,

- cosmetic kerosene as a dielectric liquid,

- flushing the inter-electrode gap through a working electrode,

- dielectric pressure during flushing $0.07 \mathrm{MPa}$,

- negative polarity of inter-electrode voltage,

- processing time $30 \mathrm{~min}$,

- set current of ignition current 2 amps,

- set voltage for the regulator $50 \mathrm{~V}$,

- amplification of the feed regulator $100 \%$, 
- no additional current pulses and bipolar voltage.

The machining was carried out only in a straight line in the $Z$ axis, with two parameter sets corresponding to medium-fine and fine machining. The machining efficiency, the relative wear of the working electrode and the roughness of the machined surface were measured. The results of eroding the $\mathrm{Al}_{2} \mathrm{O}_{3}-\mathrm{Ti}(\mathrm{C}, \mathrm{N})-\mathrm{TiB}_{2}$ composite are shown in tab. II. The results for the remaining materials $-\mathrm{Al}_{2} \mathrm{O}_{3}-\mathrm{TiC}-\mathrm{TiN}-10 \mathrm{TiB}_{2}$ and $\mathrm{Al}_{2} \mathrm{O}_{3}$ $\mathrm{TiC}-\mathrm{TiN}-30 \mathrm{TiB}_{2}$ - did not differ significantly from those summarized in the tab. II.

Based on the test results (tab. II), it was found that raising the ignition voltage to $250 \mathrm{~V}$ significantly increase the drilling efficiency and reduce the relative wear of the working electrode. The wear value of the working electrode was insignificant, despite drilling with a negative working voltage and low (0.5), as for the EDM process, the value of duty factor of current pulses. In some cases, the long-lasting machining was carried without wear of the working electrode. For comparison, during the treatment of cemented carbides under these conditions, the relative electrode wear would be several times greater.

TABLE II. Parameters of the electric erosion cutting process of $\mathrm{Al}_{2} \mathrm{O}_{3}-\mathrm{Ti}(\mathrm{C}, \mathrm{N})-\mathrm{TiB}_{2}$ material

\begin{tabular}{|c|c|c|c|c|c|c|c|}
\hline \multicolumn{4}{|c|}{ Generator settings } & \multicolumn{4}{|c|}{ Measurement results } \\
\hline$I r$ & $T i$ & $T o$ & Uzap & $\Delta M e$ & $\Delta M w$ & $d m$ & $R a$ \\
A & $\mu s$ & $\mu s$ & $V$ & mg & mg & $\%$ & $\mu m$ \\
\hline 3 & 160 & 160 & 160 & 11 & 312 & 3,53 & \\
\hline 3 & 160 & 160 & 200 & 23 & 221 & 10,41 & \\
\hline 3 & 160 & 160 & 250 & 3 & 333 & 0,9 & \\
\hline 3 & 160 & 160 & 300 & 2 & 335 & 0,6 & 1,49 \\
\hline 3 & 160 & 160 & 350 & 2 & 333 & 0,63 & \\
\hline 7 & 25 & 25 & 160 & 20 & 626 & 3,19 & \\
\hline 7 & 25 & 25 & 200 & 9 & 690 & 1,3 & \\
\hline 7 & 25 & 25 & 250 & 12 & 1008 & 1,19 & 1,62 \\
\hline 7 & 25 & 25 & 300 & 15 & 938 & 1,6 & \\
\hline 7 & 25 & 25 & 350 & 23 & 778 & 2,96 & \\
\hline
\end{tabular}

Legend: Ir-working current setting; $T i-$ pulse on-time setting; To pulse off-time setting; Uzap - ignition voltage setting; $\Delta M e$ - wear of working electrode; $\Delta M w$ - loss of workpiece material; $d m$ - relative electrode wear $(d m=100 \times \Delta M e / \Delta M w), R a$ - roughness of machined surface
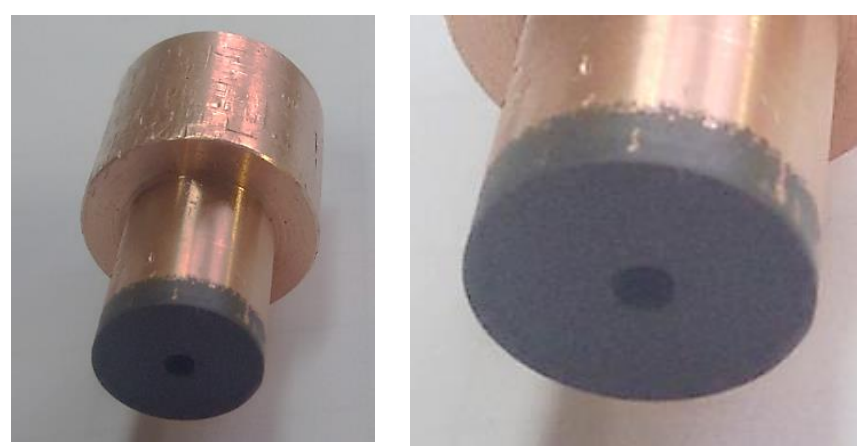

Fig. 7. Working electrode after 3-hour EDM

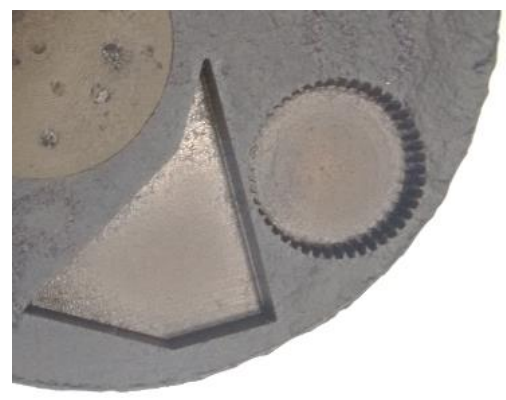

Fig. 8. EDM shaped molds in $\mathrm{Al}_{2} \mathrm{O}_{3}-\mathrm{Ti}(\mathrm{C}, \mathrm{N})-\mathrm{TiB}_{2}$ composite

Fig. 7 shows the working electrode after 3 hours of machining. The dark face and sharp edges indicated its low relative wear. Thanks to the low wear of the working electrode, electro-erosive treatment of materials with $\mathrm{Al}_{2} \mathrm{O}_{3}$ matrix can be carried out with accuracy comparable to that of steel. A small surface roughness of the machined surface was also obtained: in the case of $\mathrm{Al}_{2} \mathrm{O}_{3}-\mathrm{Ti}(\mathrm{C}, \mathrm{N})-\mathrm{TiB}_{2}$ and $\mathrm{Al}_{2} \mathrm{O}_{3}$-TiC-TiN-10TiB 2 composites $\mathrm{Ra}$ of the order of $1.5 \mu \mathrm{m}$ and approx. $0.9 \mu \mathrm{m}$ in the case of $\mathrm{Al}_{2} \mathrm{O}_{3}$-TiC-TiN-30TiB 2 . The research shows that the roughness of the machined surface depends to a small extent on the working current settings.

The EDM molding results of $\mathrm{Al}_{2} \mathrm{O}_{3}$-based ceramics with the addition of $\mathrm{Ti}(\mathrm{C}, \mathrm{N})$ and $\mathrm{TiB}_{2}$ are shown in fig. 8 .

Although the $\mathrm{Si}_{3} \mathrm{~N}_{4}-\mathrm{TiB}_{2}$ composite resistance decreases with increasing working voltage, tests have shown that the resistance was still too large for EDM machining. The reasons for this were too small working current in the available range of setting the voltage supplying the generator's circuit and too high voltage drop on the high resistance of the composite, which prevented effective operation of the inter-electrode gap regulator.

\section{Conclusions}

Most ceramic materials are characterized by high electrical resistance, therefore shaping elements from these materials is possible only with the use of waste treatment (mainly cutting and grinding), which allows to obtain details of quite simple shapes. In order to obtain more complex ceramic elements, EDM treatment is necessary, provided that the material to be machined has the proper electrical conductivity. Lowering the resistivity of ceramic materials is possible due to the use of phase additives with good electrical conductivity.

The paper presents the results of research on carbon materials with a matrix of $\mathrm{Al}_{2} \mathrm{O}_{3}$ and $\mathrm{Si}_{3} \mathrm{~N}_{4}$ with additions in the form of $\mathrm{TiC}$ titanium carbide, TiN titanium nitride and $\mathrm{TiB}_{2}$ titanium boride, which increased their electrical conductivity. The mechanical and electrical properties of conductive ceramics with $\mathrm{a} \mathrm{TiB}_{2}$ matrix were also presented.

The obtained composite materials are characterized by low electrical resistance while maintaining good physical and mechanical properties, such as density, Young's modulus and hardness.

On the basis of the EDM tests, it has been found that machining composites with $\mathrm{Al}_{2} \mathrm{O}_{3}$ matrix with $\mathrm{Ti}(\mathrm{C}, \mathrm{N})$, TiC, $\mathrm{TiN}$ and $\mathrm{TiB}_{2}$ additions of the complex shape are possible for medium-fine and exact machining. In the EDM process of these materials the working electrode wear was very low, which is important from the point of view of machining accuracy.

An important parameter of EDM machining composites with $\mathrm{Al}_{2} \mathrm{O}_{3}$ matrix is the ignition voltage of the generator. At a voltage of the order of $200 \div 250 \mathrm{~V}$, a small relative wear of the working electrode and the best performance are obtained. 
There was no positive effect of auxiliary current pulses and bipolar working voltage pulses on the EDM processing of composites. The machining of the low-conductive silicon nitride based $\mathrm{Si}_{3} \mathrm{~N}_{4}-30 \mathrm{TiB}_{2}$ composite did not give positive results due to too low current in the work circuit and faulty operation of the inter-electrode gap controller. Therefore, it is advisable to conduct research on the redesigning of the generator that will enable EDM shaping of these materials.

The research material was produced as part of the SINTERCER project - project no. 316232, Development of a SINTERing CEntRe and know-how exchange for nonequilibrium sintering methods of advanced co-frame composite materials, REGPOT-2012-2013-1 EU FP7 Research Potential. Electric discharge shaping research was carried out as part of the statutory activity of the Institute of Advanced Manufacturing Technologies.

\section{REFERENCES}

1. Pampuch R., Błażewicz S., Górny G. „Materiały ceramiczne dla elektroniki". Kraków: Wydawnictwa AGH, 1993.

2. Chen S.L., Hsu Q.C. „Studies on electric-discharge machining of non-contact seal face grooves". Journal of Materials Processing Technology. 140 (2003): p. 363-367.

3. Tomlinson W.J., Jupe K.N. "Strength and microstructure of electrodischarge-machined titanium diboride". Journal of Materials Science Letters. 12 (1993): p. 366-368.

4. Liu K., Peirs J., Ferraris E., Lauwers B., Reynaerts D. "Micro Electrical Discharge Machining of $\mathrm{Si}_{3} \mathrm{~N}_{4}$-based Ceramic Composites", http://www.4m-net.org/files/papers/4M2008/05-03/0503.PDF.

5. Manoj Kumar B.V., Ramkumar J., Bikramjit B., Kang S. "Electrodischarge machining performance of TiCN-based cermets". In ternational Journal of Refractory Metals \& Hard Materials. 25 (2007): p. 293-299.

6. Sanchez J.A., Cabanes I., Lopez de Lacalle L.N., Lamikiz A. “Development of Optimum Electrodischarge Machining Technology for Advanced Ceramics". The Internation Journal of Advanced Manufacturing Technology. 18 (2001): p. 897-905.

7. Lauwers B., Liu W., Kruth J.P., Vleugels J., Jiang D., Van der Biest O. "Wire EDM machining of $\mathrm{Si}_{3} \mathrm{~N}_{4}, \mathrm{ZrO}_{2}$ and $\mathrm{Al}_{2} \mathrm{O}_{3}$-based ceramics". International Journal of Electrical Machining.10 (January 2005).

8. Lauwers B., Kruth J.P., Liu W., Eeraerts W., Schacht B., Bleys P. "Investigation of material removal mechanisms in EDM of composite ceramic materials". Journal of Materials Processing Technology. 149 (2004): p. 347-352.

9. Yan-Cherng Lin, A-Cheng Wang, Der-An Wang, Chih-Cherng Chen. "Machining performance and optimizing machining parameters of Al2O3-TiC ceramics using EDM based on the Taguchi Method". Materials and Manufacturing Processes. 24 (2009).

10. Shuichi Kawano, Junichi Takahashi, Shiro Shimada. "Highly electroconductive $\mathrm{TiN} / \mathrm{Si}_{3} \mathrm{~N}_{4}$ composite ceramics fabricated by spark plasma sintering of $\mathrm{Si}_{3} \mathrm{~N}_{4}$ particles with a nano-sized TiN coating". Journal of Materials Chemistry. 12 (2002).

11. Oczoś K.E. "Kształtowanie ceramicznych materiałów technicznych". Rzeszów: Oficyna Wydawnicza Politechniki Rzeszowskiej, 1996.

Translation of scientific articles, their computer composition and publishing them on the website www.mechanik.media.pl by original articles in Polish is a task financed from the funds of the Ministry of Science and Higher Education designated for dissemination of science.

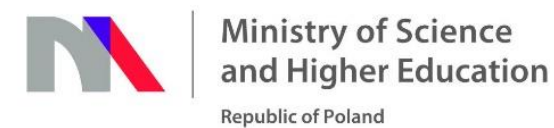

